\title{
Posições e Disposições de um corpo: o erótico e o pornográfico na ótica feminina: práticas de submissão ou de resistência nos dispositivos de poder ${ }^{1}$
}

\author{
Positions and dispositions of a body: the erotic and the pornographic in the feminine vie: \\ submission practices or resistance in power devices
}

\section{Georgia Amitrano'}

Resumo: O presente artigo/ensaio é um olhar outro para o foco da lente filosófica que não abarca, ainda, a questão do amor, do corpo e do corpo feminino como possibilidade real do filosofar. A análise visa entender como os corpos femininos foram pensados e como ainda o são no universo falocêntrico e em certas correntes feministas. E isso é realizado a partir da estética e da política erótica e pornográfica, pensadas como possibilidades de resistência diante da negação do Ser da mulher. Erótica e pornografia são entendidas aqui como conceitos que também não se ajustam ao foco filosófico do que se chama 'boa filosofia'. Palavras-chave: Corpo; Erótico; Pornográfico; Mulher; Dominação

\begin{abstract}
The present article/essay is another look to the focus of the philosophical lens which does not yet embrace the question of love, body and female body as a real possibility of philosophizing. The analysis aims to understand how the female bodies were thought and how they still are in the phallocentric universe and in certain feminist currents. And this is accomplished from the aesthetic and erotic and pornographic politics, thought of as possibilities of resistance in the face of denial of The Being woman. Erotic and pornography are understood here like concepts that also don't fit into the philosophical focus of what is called the "good philosophy".
\end{abstract}

Keywords: Body; Erotic; Pornographic; Woman; Domination

Um convite, um texto, um encontro. Aqui há uma escrita forjada na aventura de pensamentos sobre o corpo, o erótico e o amor. Eis o texto que aqui se apresenta. Um ensaio, porque gosto de ser ensaísta, que nasce no segundo encontro Erotismo e Filosofia, na cidade de Goiás. Todavia, é mais que uma fala apresentada, é fruto de um trabalho de pesquisa para um livro, que hoje já se encontra no prelo. Donde na confecção de uma teia - que vai da pesquisa, incluindo algumas conferências, para um projeto maior, o livro que por mim fora escrito -, eis um retalho, com uma escrita repleta de reticências, aspas, parênteses, palavras grifadas, riscos. É uma nova costura que emerge nesse conjunto de expressões (parole, mot) que vão do amor, passam pelo erótico e se jogam ao pornográfico na tentativa de falar do corpo através da filosofia. Um corpo erótico, que cheira, que goza, que treme, que ama. Estou aqui, então, para falar do que nós filósofos nos furtamos, o amor como possibilidade corpórea. Isso talvez seja a coisa mais difícil para um filósofo pensar...

Professora Associada do Instituto de Filosofia da Universidade Federal de Uberlândia-UFU e do Programa de Pós- Graduação em Filosofia-UFU. Doutora pela UFRJ.

${ }^{1}$ O título do texto é o mesmo da conferência proferida na Cidade de Goiás por ocasião do segundo Simpósio

Erotismo e Filosofia. O texto possui algumas modificações para publicação. 
Afinal, amar requer um corpo que geme...

Atualmente, a filosofia não diz nada do amor, ou muito pouco. Além disso, é melhor esse silêncio, diante do tanto que o maltrata ou o trai quando se arrisca dele falar. Eu quase poderia duvidar que os filósofos o experimentam, se não supuséssemos que aquilo que mais temem é dizer sobre ele. E com razão, pois sabem melhor que ninguém que não dispomos das palavras para dele dizer, nem de conceitos para pensá-lo, nem de forças para celebrá-lo. De fato, os filósofos o deixaram em abandono, destituíramno de conceito e, finalmente, o atiraram às margens obscuras e inquietas de sua razão suficiente - como o reprimido, o não-dito e o inconfessável. Sem dúvida, outros discursos pretendem revelar esta deserdação, e por vezes logram êxito. A poesia pode dizer-me da experiência com ele, mesmo sem saber articulá-lo, me liberando assim de minha afasia erótica - mas nunca me fará compreender o amor em seu conceito. A novela vem para quebrar o autismo da minha crise amorosa, porque ela me reinserta em uma narrativa social, plural, pública - mas não explica o que a mim realmente sucede. A teologia, por sua vez, sabe do que se trata, mas não o sabe tão bem de modo a evitar sempre impor uma interpretação tão direta mediante à Paixão que chega a anular minhas paixões -sem dispor de um tempo para fazer justiça à sua fenomenalidade, ou dar sentido à sua imanência. A psicanálise pode resistir a esse apuro e sabe se demorar sobre minhas vivencias conscientes e todo inconsciente, mas apenas para comprovar ainda mais a falta de palavras para dizê-las, donde até mesmo a psicanálise em si carecer de conceitos para pensá-las. Diante desses débeis esforços, resulta que o recém chegado, quer dizer, todos aqueles que amam sem saber bem o que quer dizer o amor, no que ele exige, e, especialmente, como sobreviver a ele -vocês e eu primeiro- acreditamse condenados aos piores subterfúgios: o sentimentalismo efetivamente desesperado da prosa, a indústria pornográfica frustrada, os ídolos ou ideologias que idealizam a plenitude individual, essa asfixia prepotente. Assim, a filosofia se cala, em seu silêncio, o amor desaparece2.

Falar do amor é algo que a filosofia sempre se furtou. Sim, sempre se furtou. Afinal, descrever o Eros à luz da razão não é o mesmo que falar do amor. Este implica, necessariamente, dizer do Corpo, falar de corpos trêmulos, de um coração palpitante, do jogo dos olhares que se encontram e se desviam. Falar do amor implica não conseguir agir diante da razão tal qual apregoada. Há sudorese, há tremores, fala gaguejante, espasmos, pensamentos discordantes... sonhos ardentes, comportamentos inapropriados. E, mesmo que tenhamos análises bioquímicas, cientificamente respaldadas, não fugimos à ação desconexa com nossos julgamentos. Falar do amor, portanto, nos obriga a falar do corpo. Mas de um tal corpo cuja nudez absoluta - no jogo que escapa aos hormônios, e sua explicação endócrina, neuronal - nunca é totalmente vista com os bons olhos destinados à boa filosofia.

Ora, o título deste trabalho, ensaio, texto é Posições e Disposições de um corpo: o erótico e o pornográfico na ótica feminina, práticas de submissão ou de resistência nos dispositivos de poder; e o que eu quero dizer com isso?

Como aquela que se propõe a filosofar, não sou capaz de escapar totalmente (se é que de fato escapo em algum momento) àquilo que me constitui na atividade de meu exercício. Travo, portanto, um embate psíquico e corpóreo entre o que quero dizer e o que posso falar. Os conceitos e os autores gritam, apaixonadamente, na minha cabeça. Donde aqui, neste texto/ensaio, a ambiguidade aparece. Agirei como a filósofa. Sim, claro

2 MARION, El fenómeno erótico, p. 9-10. 
que agirei. Demonstrarei a história do corpo, do corpo da mulher, dos conceitos de poder, submissão e resistência. Trarei os autores, a mim muito caros no pensamento e na história da Filosofia. Mas, de certo modo, tentarei, através da erótica e do pornográfico, me ater ao amor, àquilo que a filosofia não quer, ou não é capaz de falar. Se conseguirei, isso só os que a mim forem ler serão capazes de me dizer...

\section{Comecemos...}

O corpo existe e pode ser pego.

É suficientemente opaco para que se possa vê-lo.

Se ficar olhando anos você pode ver crescer o cabelo.

O corpo existe porque foi feito.

Por isso tem um buraco no meio.

O corpo existe, dado que exala cheiro.

E em cada extremidade existe um dedo.

O corpo se cortado espirra um líquido vermelho.

O corpo tem alguém como recheio.

(Arnaldo Antunes, O Corpo)

O corpo sempre apareceu como uma questão para a Filosofia, mas não como um dos bons problemas. Ele é um impasse para a razão. Uma estrutura que liga o mais notável ao mundo sensível, uma parte do Ser muitas vezes desprezada; afinal, exala cheiro e dele escorre um líquido vermelho. Ele pulsa e geme. O corpo nos traz dificuldades para alcançar o ideal porque emudece...

Desde os primórdios do filosofar há a necessidade de descartá-lo, colocá-lo à margem, tratar-lhe como menos importante. Sem ingenuidades, e ciente que não se pode escapar ao corpo, este nunca foi evidentemente valorado como objeto fundamental para a Filosofia. E nós ainda, com os mais atuais modelos de pensamento, não nos esquivamos totalmente desses discursos. Todavia, o corpo não pode ser negado, e a causa é simples e evidente: somos seres corpóreos, somos matéria, e disso não há como escapar. A alma, o espírito, a mente, a mente como cérebro, etc. Tudo se acopla ao corpo.

Ora, desde Platão, emergimos como uma dupla natureza. O que o senso comum (e muitos filósofos) mantém nos discursos que impregnam nossos cotidianos. Esta natureza dupla é dissociada e contrária. Se, por um lado, com Platão (e/ou desde ele), o corpo representa o sensível, seu contrário, a 'alma', representa o inteligível, a razão, e está próxima ao divino.

O corpo, assim, não emerge como um elemento essencial para alcançar a sabedoria, a verdade, não é capaz de mover a si mesmo e as demais coisas; ao contrário, é, para tais conquistas, um obstáculo. No máximo, apresenta-se como um primeiro passo, uma ligadura necessária, mas que é sempre incompleta, presa aos animais (no modo que temos de subestimá-los). Donde o centro das atenções filosóficas- seja dos textos platônicos, de seus comentadores, e de toda uma gama filosófica posterior - geralmente não é voltado diretamente ao corpo; antes, à alma (ou ao nome que passemos a dar a ela dependendo da ocasião, filósofo ou período histórico).

O corpo, portanto, é inexato devido ao seu caráter de apreensão sensível.

Uma pausa nesse momento. Mas há autores, diriam alguns. Nietzsche, por exemplo, enaltece o corpo. Mas, há sempre um "mas", para além de Nietzsche, existem "os filósofos", aqueles que tendem a menosprezar seu trabalho e os que dele retiram uma filosofia do corpo. Então, vamos deixá-lo de lado, por ora.

Falemos, pois, de Aristóteles, este, falariam alguns outros, não se comporta 
| Posições e Disposições de um corpo: o erótico e o pornográfico na ótica feminina: práticas de submissão ou de resistência nos dispositivos de poder

assim. Será que não? Ou melhor, será realmente que na ordem discursiva apreendida ao longo dos séculos, efetivamente demos vasão aos sentidos, do ponto de vista de apetites fundamentais e corpóreos? Ou deles buscamos os predicados mais afastados da verdade? O corpo, como objeto sensível, ainda é o último, o mais primitivo, a mais inferior forma de conhecimento, mesmo que seja a primeira.

Obviamente, tal qual Platão, Aristóteles não vê a alma como algo simples, muito pelo contrário, sua complexidade é tal que não a compreende no singular; antes, tratamse de almas. Há um plural (três 'almas' ou faculdades ${ }^{3}$ ). Todavia, suas funções e faculdades ainda são hierarquizadas segundo aquilo a que cada alma pode realizar. Não é em vão que mantém, e de maneira bem contundente, uma distinção, pondo a razão em uma dada posição superior com relação aos apetites. Para Aristóteles, mesmo compreendendo que apetites são constitutivos do homem, estes ligam-se diretamente ao corpo e não à razão. Afinal, na alma, enquanto faculdade racional (alma intelectiva), o puro ato do conhecimento, o desejo que aparece como vontade só pode ser compreendido como um desejo racional, o que o faz se contrapor aos apetites, àquela parte irracional do homem, seu traço comum com os animais. O desejo racional não se dirige a qualquer fim ou a qualquer objeto; antes, a um fim prévio determinado pela razão. E, na ordem dos discursos, até hoje, o corpo fica mais uma vez relegado a um segundo plano, incompleto, restrito e incapaz de abarcar um conhecimento maior, nem mesmo naquilo que deseja.

Ora, meu trabalho aqui não é descartar filosofias, tampouco passear por toda a história do pensamento ${ }^{4}$. Do mesmo modo não se trata de negar o que determinados pensadores falaram acerca do corpo e de sua importância. O que importa são os discursos, as falas que atravessam o tempo e que dizem da negação, controle, subjugação, repressão dos corpos. Corpos que transbordam apetites, desejos não considerados racionais.

Há corpos que emanam amor. Não o amor romântico, mas aquele que espelha o próprio do comportamento humano, nossas paixões. Entendendo paixão como o ato de sofrer a ação de um agente exterior, o qual afeta praticamente o indivíduo todo, o nosso organismo e o nosso psiquismo. Reagindo sobre o nosso corpo, na extensão de nossos órgãos.

Mas, afinal, de que corpo ou corpos, melhor dizendo, eu falo aqui? Em um olhar atento acerca da história do corpo, este não pode ser pensado somente como algo comum a todos os indivíduos. Há mais de um corpo. E, se filosofamos acerca do corpo, não é bem do corpo feminino que falamos. E é desse corpo que eu quero dizer agora. Afinal, este texto/ensaio trata das "Posições e Disposições de um corpo", e não do corpo. É do corpo da mulher e das práticas e discursos sobre ele que traço a sequência desta minha tessitura, que é feita dos retalhos da minha costura maior.

Como já afirmara Nietzsche,

É de importância decisiva quanto ao destino dos povos e da humanidade que a cultura comece no lugar certo - não na "alma” (tal como era a funesta superstição dos sacerdotes e semi-sacerdotes): o lugar certo é o corpo, o gesto, a dieta, a fisiologia, o resto é consequência ${ }^{5}$.

\footnotetext{
3 A primeira alma, presente no Homem, nas plantas e nos animais, é a "vegetativa", que regula funções como a nutrição e a reprodução. A segunda, presente no Homem e nos animais, é a alma "sensível", que é responsável, dentre outras coisas, pelas sensações. O apetite nasce em consequência da sensação: "Todos os animais têm pelo menos um sentido, ou seja, o tato. Mas quem tem a sensação sente prazer e dor, o agradável e o doloroso. E quem os experimenta tem também desejo: com efeito, o desejo é o apetite do agradável". Para Aristóteles uma das maiores virtudes éticas é o triunfo da razão - que está ligada à terceira alma, a "Intelectiva”, presente apenas no Homem, e responsável pela assimilação das formas inteligíveis - sobre os impulsos irracionais, como o desejo.

4 Descartes, por exemplo, não despreza o corpo, pois, sem ele, a alma não teria motivo de existir. Seu sentido se dá na união corpo/alma. E, tal união, não tira a particularidade de cada um e nem forma outra substância a partir destas duas. Todavia, ainda se vê em Descartes a superioridade da alma em relação ao corpo.

5 NIETZSCHE, Crepúsculo dos ídolos, p. 100.
} 


\section{O Corpo feminino: um algo a parte}

Ora, somos cientes da existência de um corpo ao qual é imposta uma identidade, um lugar já demarcado e próprio no mundo e que é regido por entre paredes labirínticas de certas normas morais. Há, portanto, um corpo cujo "sexo" designa não somente uma identidade como também uma possível castração sobre ele. Para além, este corpo é disposto de acordo com um prazer alheio a ele.

É deste corpo e de sua sexualidade que emergem papéis sociais complexos, os quais se deitam desde a maternidade, observando-a como divindade e pecado, e até mesmo dando a possibilidade implícita (e em muitos casos explícita) de sua violação. Lembremos que a mulher se encontra desde o princípio sem um existir pessoal, o Ser da mulher se dá, na maioria das culturas, numa forma de existência condicionada ao ser de um outro, o Ser do Homem (macho, pai e provedor). Há, assim, uma espécie de pertencimento a alguém (ela é esposa, mãe, filha, objeto, etc.). Não há igualdade de Ser; antes, à mulher lhe é negado seu Ser próprio. O que faz, consequentemente, a ela (a mim, a nós mulheres) ser negado, também, seu (nosso) prazer, seu (nosso) desejo e sua (nossa) sexualidade para fora dos desígnios culturais de uma sociedade falocêntrica, machista e patriarcal.

\section{Detalhes míticos e históricos}

Obviamente há autores que afirmam um destaque à mulher, ao feminino. Na mitologia grega as figuras das deusas Artêmis, Atena, Afrodite, Deméter, Hera, Perséfone, Pandora e Gaia são uma constante ao longo do pensamento e da história da Grécia. Todavia, a inteligência e o pensamento representados pela deusa Atena apontam para uma existência diferenciada desta, haja vista nascer, não do corpo de sua mãe, mas da cabeça de seu pai, Zeus. Uma de suas maiores características é a sua virgindade. Além disso, dos mitos gregos, o que fica sobre o que se diz da Mulher não são as Deusas, elas não são mulheres... O que fica é Pandora. Um 'Ser' cujo corpo não é criado, mas fabricado sob encomenda de Zeus para "presentear" os homens como um Cavalo de Tróia. Somos, portanto, aquelas que trazem problemas aos homens mortais entre os quais vivem 6 .

Mas não só dos gregos vivem os homens, o Judaísmo e Cristianismo, religião que anima a cultura ocidental, tornaram-nos um objeto pertencente ao corpo do homem, somos sua costela. E a ele devemos servir, silenciosas, subservientes.

E é desse silêncio e subserviência, acrescido da nossa dissimulada conduta, do nosso espírito de cão, que nos tornamos mentirosas sedutoras, mas apenas para servir

\footnotetext{
Nos poemas da Teogonia e de Os Trabalhos e os Dias, a mulher (Pandora) é uma bela e deleitável forma de virgem pudente, apresentada aos deuses e aos homens que se espantam ao ver a maravilha criada. Mas essa maravilha é a contrapartida de um roubo, portanto, contrapartida de um dolo. Pelo fogo roubado "nasce" a primeira mulher, um ser de um ardil incombatível. A Mulher fabricada por Hefesto é "algo" dado a ver, que se admira. Mas, como tudo o que encanta, é exterioridade, invólucro de um engano, mal reverso de um bem. "E criou já ao invés do fogo um mal aos homens:/plasmou-o da terra o ínclito Pés-tortos/como virgem pudente, por desígnios do Cronida;/cingiu e adornou-a a Deusa Atena de olhos glaucos/ com vestes alvas, compôs um véu laborioso/descendo-lhe da cabeça, prodígio aos olhos,/ao redor coroas de flores novas da relva/sedutoras Ihe pôs na fronte Palas Atena/e ao redor da cabeça pôs uma coroa de ouro,/quem a fabricou: o ínclito Pés-tortos/lavrando-a nas mãos, agradando a Zeus pai,/e muitos lavores nela gravou, prodígio aos olhos,/das feras que a terra e o mar nutrem muitas/ele pôs muitas ali (esplendia muita a graça)/prodigiosas iguais às que vivas têm voz./Após ter criado belo o mal em vez de um bem/levou-a lá onde eram outros Deuses e homens/adornada pela dos olhos glaucos e do pai forte./O espanto reteve Deuses imortais e homens mortais/ao virem íngreme incombatível ardil aos homens./Dela descende a geração das femininas mulheres./Dela é a funesta geração e grei das mulheres,/grande pena que habita entre homens mortais,/parceiras não da penúria cruel, porém do luxo./Tal quando na colmeia recoberta abelhas/nutrem zangões, emparelhados de malefício,/elas todo o dia até o mergulho do sol/diurnas fadigam-se e fazem os brancos favos,/eles ficam no abrigo do enxame à espera/e amontoam no seu ventre o esforço alheio,/assim um mal igual fez aos homens mortais/Zeus tonítruo: as mulheres, parelhas de obras/ásperas, e em vez de um bem deu oposto mal". (HESíODO, Teogonia, p. 49).
} 
Posições e Disposições de um corpo: o erótico e o pornográfico na ótica feminina: práticas de submissão ou de resistência nos dispositivos de poder

ou ganhar vantagens. Nosso corpo, assim, não é um corpo de prazer próprio, mas forjado para dar prazer ao homem. Nossos desejos sexuais inexistem para além da vontade do falo, de sua ereção e gozo, no prazer próprio ao macho. Nosso corpo, portanto, na tradição e cultura enraizadas desde sempre (podemos ir ao oriente árabe, nipônico, África, com raras exceções), não nos pertence, está à disposição de outrem. Tampouco nosso prazer, desejos, estímulos sexuais nos pertencem, estão postos e dispostos como oferendas ao homem...

\section{Do Controle à Resistência}

Bourdieu, em A Dominação Masculina, afirma que:

Como estamos incluídos, como homem ou mulher, no próprio objeto que nos esforçamos por apreender, incorporamos, sob a forma de esquemas inconscientes de percepção e de apreciação, as estruturas históricas da ordem masculina; arriscamo-nos, pois, a recorrer, para pensar a dominação masculina, a modos de pensamento que são eles próprios produtos da dominação. Não podemos esperar sair deste círculo se não encontrarmos uma estratégia prática para efetivar uma objetivação do sujeito da objetivação científica. ${ }^{7}$

Ora, por mais que tenhamos, ao longo do último século galgado direitos, aberto espaços, a dominação masculina, no modo como é infligida e vivenciada, resulta daquilo que o filósofo chama "de violência simbólica, violência suave, insensível, invisível a suas próprias vítimas, que se exerce essencialmente pelas vias puramente simbólicas da comunicação e do conhecimento, ou, mais precisamente, do desconhecimento, do

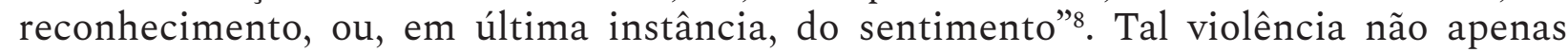
inflige dor, insegurança; mas antes, impõe regras de condutas tais que, na maioria das vezes, impossibilita enxergar o quão reféns somos do sistema.

O corpo feminino, assim, é objeto de prazer alheio, independente do ganho direto de direitos a nós atribuídos. O que quero dizer é que não escapamos, ainda, e por mais que queiramos, ao sistema, à cultura, aos jogos de poder e força, aos discursos muitas vezes mantidos por nós mesmas. Estamos submetidas, assim, a toda uma estrutura social que nos condena a reprodução de padrões de controle, repressão, etc.

Na grande maioria das vezes, ratificamos, através de discursos (que não percebemos em muitos casos) a dominação masculina ou os mesmos modos de dominação, e ainda achamos que escapamos a ela.

Mas há algum escape afinal? Creio que sim, mas não é algo simples, com visibilidade plena, não é ainda coletivo do modo como se pensa. As resistências estão postas e novas posições de controle, ou não, podem emergir daí. Mais uma vez Bourdieu:

O uso do próprio corpo continua, de forma bastante evidente, subordinado ao ponto de vista masculino [...]: o corpo feminino, ao mesmo tempo oferecido e recusado, manifesta a disponibilidade simbólica que, como demonstram inúmeros trabalhos feministas, convém à mulher, e que combina um poder de atração e de sedução conhecido e reconhecido por todos, homens ou mulheres, e adequado a honrar homens de quem ela depende ou aos quais está ligada, com um dever de recusa seletiva que acrescenta, ao efeito de "consumo ostentatório", o preço da exclusividade. ${ }^{9}$

BOURDIEU, A dominação masculina, p. 15.

8 BOURDIEU, A dominação masculina, p. 7.

9 BOURDIEU, A dominação masculina, p. 40. 
O corpo feminino, então, serve ainda ao prazer masculino, sejam nas revistas, nos comerciais, nas estórias de ficção (boa parte delas). Nosso sexo, com todo o nosso desejo e gozo já é a nós permitidos, porém, ainda sustentam o prazer, o gozo do outro, do homem. Vivemos o prazer, mas não o de nossos olhos ou corpos ávidos pelo cheiro, mãos, pelo falo ereto; antes, vivemos para dar o prazer a esse falo ereto. Somos, portanto, dispostas como mercadorias, e isso ainda não mudou. Permanece na base social e cultural. E, ao negarmonos falar do corpo, negamos a filosofia em parte de sua antropologia, nos esquivamos do mundano, mantemos o rompimento entre a vida dos humanos (por falta de melhor palavra) como ação e nos jogamos na contemplação, longe, sempre longe do corpo, mais distante ainda do corpo feminino.

A partir daqui a questão que se põe é: Podemos nos manter nesse mundo tal como estamos dispostas? Devemos negar toda essa forma de prazer e gozo instituídos? Qual o caminho, se é que há um caminho?

Foucault em na entrevista, "sexo, poder e a política da identidade”, afirma:

\begin{abstract}
Não somos presos, então. Acontece que estamos sempre de acordo com a situação. O que quero dizer é que temos a possibilidade de mudar a situação, que esta possibilidade existe sempre. Não podemos nos colocar fora da situação, em nenhum lugar estamos livres de toda relação de poder. Eu não quis dizer que somos sempre presos, pelo contrário, que somos sempre livres. Enfim, em poucas palavras, há sempre a possibilidade de mudar as coisas [...] A resistência vem em primeiro lugar, e ela permanece superior a todas as forças do processo, seu efeito obriga a mudarem as relações de poder. Eu penso que o termo 'resistência' é a palavra mais importante, a palavra-chave dessa dinâmica. ${ }^{10}$
\end{abstract}

Haveria na ética do "cuidado de si”, em um conjunto de regras de existência que o sujeito dá a si mesmo, a ascensão, segundo sua vontade e desejo, de uma forma ou estilo de vida que culminaria em uma "estética da existência". Ora, é no voltar-se a si mesmo, de modo reflexivo, mas expresso corporalmente, que podemos, de certo modo, e em alguns momentos, alcançar a liberdade, ofertando-nos regras de existência próprias e distintas de padrões e normas ditadas pelas relações sociais. Esculpimos, assim, como obra de arte, nossas vidas e subjetividades.

É neste ponto que quero trazer a pornografia feminista como possibilidade de resistência do feminino, como amor, como cuidado de si. Uma estética de existência na qual podemos dizer sem muito receio: meu corpo, nossos corpos como obra de arte. Desejo e prazer, sem a negação ao outro, mas sem a objetificação da mulher.

\title{
Falemos, pois da pornografia...
}

(Que nesse caso será bem mais erótica, se assim se pode separar)

Eliane Robert Morais, em uma entrevista, afirma que “A pornografia é uma espécie de fome. Como tal, ela pode ser saciada de diversas maneiras, seja com um salgadinho industrializado, seja com um banquete. E, claro, com tudo o que há entre um e outro...” (https://azmina.com.br/reportagens/a-pornografia-e-uma-fome-podemos-sacia-la-comum-banquete-ou-um-salgadinho)

Antes, porém, e Eliane nos faz lembrar, na introdução aos 120 Dias de Sodoma, Sade já afirmava esta fome.

${ }^{10}$ FOUCAULT, Michel Foucault, uma entrevista: sexo, poder e a política da identidade, p. 268. 
Trata-se da história de um magnífico banquete [diz Sade] - seiscentos pratos diferentes se oferecem ao teu apetite: vais comê-los todos? Não, seguramente não, mas essa prodigiosa variedade alarga os limites da tua escolha e, extasiado com a ampliação das possibilidades, certamente não te queixarás do anfitrião que te presenteia. Escolhe e deixa o resto sem reclamar. Conta esse resto simplesmente por não te agradar. Imagina que ele possa encantar aos outros e sê filósofo. ${ }^{11}$

Ora, venho eu aqui conjugar ou conjurar pornografia e feminismo, apontando para uma disposição e jogos de posições dos nossos corpos, em uma possível resistência e superação de ditames sociais. Uma abertura imaginável para dizer dessa fome de amor na filosofia.

Uma questão polêmica na obviedade do tema; afinal, a grande maioria das feministas analisa o tema como um problema de ordem político-igualitária, apoiandose no argumento de que a pornografia é uma indústria de manutenção da misoginia, o que ameaça a instauração de igualdade concreta sociopolítica entre homens e mulheres. A difusão da pornografia mantém o modo como as mulheres são percebidas no espaço público. Muitas feministas, procuram, assim, igualar a pornografia a outras expressões de ódio e intolerância, como o racismo e a homofobia

Catharine MacKinnon e Andrea Dworkin, por exemplo, advogam a censura de certos materiais pornográficos. Tal recriminação, contudo, não reside no fato de que o material mostre nudez ou atos sexuais, não seria uma questão moralista. O problema estaria no dano que a mistura de sexo com violência e coerção causa às mulheres, seja na própria produção, seja posteriormente, no uso e divulgação do material. Do mesmo modo, para esta corrente feminista, a pornografia causa a desumanização das mulheres e mantém uma subordinação destas aos homens. Questões com as quais eu concordo.

Todavia no jogo discursivo ao qual Mackinnon se apresenta, o modo de negação, ou melhor, o combate às estruturas pornográficas se une a exclusão, mais uma vez, do corpo, do desejo, do prazer femininos. Constrói-se uma 'casta' mínima de mulheres capazes de reconhecer e desejar seu corpo, e ainda, de sentir prazer.

MacKinnon afirma que

A sexualidade é para o feminismo o que o trabalho é para o marxismo: aquilo que mais nos pertence, e o que mais nos é tomado [...]. Assim como a expropriação organizada do trabalho de alguns para o benefício de outros define classe e trabalhadores, a expropriação organizada da sexualidade de algumas para o uso de outros define sexo e mulheres. ${ }^{12}$

Pela pornografia, as mulheres são transformadas em artefatos sexuais e se reproduz a noção segundo a qual elas existem para prover prazer sexual aos homens. A mesma MacKinnon ainda entende que a relação sexual heterossexual (penetração) é sempre um estupro.

Numa sociedade patriarcal, toda relação sexual heterossexual é estupro porque as mulheres, como um grupo, não são fortes o suficiente para consentir. ${ }^{13}$ Compare os relatos de vítimas de estupro com o de relatos de sexo das mulheres. Eles se parecem muito [...] A maior distinção entre coito (normal) e estupro (anormal) é que o normal acontece tão frequentemente que alguém não pode fazer os outros enxergarem que há algo de errado nisso. ${ }^{14}$

\footnotetext{
11 SADE. Histoire de Juliette, p.79.

12 MacKinnon, Feminismo, Marxismo, Método e o Estado: Uma agenda Para Teoria, p. 798.

13 MACKINNON, Professing Feminism: Cautionary Tales from the Strange World of Women's Studies, p. 129.

14 MACKINNON, Toward a Feminist Theory ofthe State, p. 146.
} 
Ora, lembremos de Bourdieu, citado por mim anteriormente: "Como estamos incluídos, como homem ou mulher, no próprio objeto que nos esforçamos por apreender, incorporamos, sob a forma de esquemas inconscientes de percepção e de apreciação, as estruturas históricas da ordem masculina”.

Não nego, em momento algum, a existência de um comportamento machista, misógino, coercitivo, objetificador da mulher na maciça produção pornográfica que vivemos por séculos. Todavia, o discurso de Mackinnon não foge, pelo menos a mim parece, ao discurso subalternizador, que inferioriza a mulher. Nas palavras da feminista acerca do sexo heterossexual com penetração, "a maior distinção entre coito (normal) e estupro (anormal) é que o normal acontece tão frequentemente que alguém não pode fazer os outros enxergarem que há algo de errado nisso"; ou ainda, "Numa sociedade patriarcal, toda relação sexual heterossexual é estupro porque as mulheres, como um grupo, não são fortes o suficiente para consentir”. Em outras palavras, a filósofa e feminista coloca a mulher em um papel de incapaz (pelo menos neste período histórico que vivemos) de se dar conta de seu desejo, de seu prazer, de seu gozo. Seu discurso ainda, mesmo que ela não queira ou se aperceba, é um discurso que hierarquiza o pensamento, diferenciando modelos de poder a partir da inferioridade daquelas tidas como fracas, as mulheres. Haveria, na leitura de Mackinnon, um grupo mais forte dessas mulheres, mas a maioria não se dá conta de seu corpo, seu desejo e de seu intelecto.

Nós, portanto, eu e outra mulher qualquer (que não tenha a capacidade intelectiva alcançada por Mackinnon) somos vulneráveis a tal ponto, que não sentimos quando sentimos. Nós não gozamos quando gozamos, não temos nossos corpos arrepiados no êxtase do prazer, como 'um' nosso prazer. Somos, portanto, incapazes de saber o que queremos com relação ao nosso sexo, como o queremos, como gostamos. Nosso corpo continua como pecado, mesmo que o termo não seja nunca usado.

Incapazes de ter fetiches, vontades, volúpia. Tudo, na ordem dessa discursividade, impede minha autossuficiência com relação ao meu corpo. Então, estamos, pelo menos temporariamente, presas a essa situação, incapazes de resistências individuais?

"Não somos presos, [diz Foucault]. Acontece que estamos sempre de acordo com a situação. [...] temos a possibilidade de mudar a situação, que esta possibilidade existe sempre". ${ }^{15}$ Mais uma vez, sem negar a existência de um universo pornográfico misógino e objetificador do feminino, vejo a resistência, não como um artefato vindo do exterior. Não há uma comoção coletiva que derruba pré-conceitos e constrói direitos. Antes, percebo esta resistência como estética, como um cuidado de si, uma possibilidade de abertura às multiplicidades, ao encontro, ao impossível. Como diz Foucault, em uma entrevista a Roger-Pol Droi

ao imprevisível... essa maneira de interrogar a história a partir de seus jogos de possibilidade e de impossibilidade é, ao meu olhar, a mais fecunda, quando se quer fazer uma história política e uma política histórica. No limite, pode-se pensar que o mais impossível que se torna, finalmente, o mais necessário. É preciso dar o máximo de chance ao impossível e dizer: como essa coisa impossível, efetivamente, aconteceu? ${ }^{16}$

E é como política que a pornografia feminista existe, resistindo por dentro. Afinal, é meu gozo, meu corpo, meus olhos fixos nos seus, minha vulva, meu desejo, meu prazer. Na ordem discursiva das coisas, um discurso outro emerge. E nele a pornografia diz do desejo, do corpo, do amor feminino, de um Eros próprio à mulher. Não é mais a mulher submissa pelo jogo patriarcal. Se submissão houver esta se dá na escolha pelo meu/nosso prazer.

\footnotetext{
15 FOUCAULT, Michel Foucault: entrevista, p. 18.
}

16 FOUCAULT, Michel Foucault: entrevista, p. 20. 
| Posições e Disposições de um corpo: o erótico e o pornográfico na ótica feminina: práticas de submissão ou de resistência nos dispositivos de poder

Não mais a fêmea que apenas goza no gozo do macho, mas seu gozo agora é protagonista. Pornografia feminista é, portanto, política, e política é ação. Desde Aristóteles se diz dela através do discurso.

\section{Erika Lust e uma estética pornográfica feminista}

Nesse lugar incomum, algumas mulheres se destacam, dentre elas a Diretora de filmes pornográficos e cientista política, Erika Lust. E é dela e com ela e seus filmes que começo a finalizar o meu também discurso político feminista.

"A excitação é doce, mas a objetificação da mulher é amarga", esse foi o sentimento que a cineasta Erika Lust sentiu ao assistir um filme pornô pela primeira vez. Em uma palestra no TedxViena, ela diz:

Pornografia estilo pau-do-tamanho-de-uma-tromba-na-boca-da-loiraplatinada-de-batom-vermelho-que-gania nunca foi uma coisa sussa ou excitante para mim - e eu frequentemente tinha acessos de riso porque meu deus, não é disso que eu gosto, não é isso que eu espero de sexo, não, não. Mas ao mesmo tempo era sexo e mesmo aquela fodelança plástica mexia com meu desejo, então sempre foi uma coisa confusa. Eu não sabia dizer o que me incomodava e apenas dizia que "não gostava de pornô". ${ }^{17}$

A sensação do "não gostar do pornô" se misturava com o desejo, com tesão. Com o corpo ávido por gozo e prazer, Erika percebe o que a incomoda na filmografia pornográfica, e não é o sexo, mas o modo como ele é apresentado. Como o corpo feminino é posto e disposto, de modo a favorecer exclusivamente ao desejo do homem. À mulher cabe o papel de objeto, como diz a cineasta, para punhetas.

Ora, Erika é ciente que a pornografia faz parte da cultura ocidental, e a atinge profundamente, mantendo um aspecto e um comportamento misógino e machista, no qual a mulher é objetificada. Todavia, o fato de haver uma pornografia objetificante da mulher não exclui esta de ter desejos, sentir prazer, querer orgasmos ou apenas ver, assistir pornografia. Progressivamente, com o ganho de direitos e a "liberdade sexual feminina", o que se percebe é o anseio de uma parcela significativa de mulheres que almejam assistir, 'voyeuristicamente' ou não, à práticas sexuais (eróticas e pornográficas) relacionadas ao prazer e ao corpo feminino. Afinal, nós temos, sim, excitação corpórea, fluidos, sangue, pele e pelos eriçados, e podemos ou não nos deliciar com determinados filmes.

Aqui reside a resistência política de Erika, uma estética do corpo como cuidado de si. A moça sueca, que estudou ciências políticas, muda-se para Barcelona, e decide transformar misoginia e machismo em força artística e discursiva. Reconfigurando a indústria pornográfica, os filmes de Erika possuem um erotismo de luz. As imagens e histórias são sobre sexo, mas diferentemente do que é conhecido o desejo advém de um outro. O corpo que fala e que goza é agora o da mulher. O sexo deixa de ser plástico.

Através de uma arte erótica feminina, os discursos pornográficos instituídos começam a ser confrontados. Hoje mais de $50 \%$ dos assinantes e compradores de seus DVds e canal são homens. Afinal, Erika se comprometeu a criar novas ondas no cinema adulto. Em suas palavras: "Eu quero mostrar toda a paixão, intimidade, amor e luxúria em sexo, onde o ponto de vista feminino é vital”. E, eu afirmo, amor, sexo e luxúria não tem gênero.

17 LUST, Erika. Pornografia Feminista. Disponível em: < http://lugardemulher.com.br/erika-lust-e-a-pornografia-feminista/> . 
Ao fazer ela mesma seus próprios filmes, olhando para a mulher através do desejo feminino, sublinha a possibilidade da força feminista em um universo tão marcadamente masculino e machista quanto o pornô. Donde sua pornografia dever ser entendida como política.

\section{Finalizando...}

Hilda Hilst havia dito certa vez

Existe um grande preconceito contra a mulher escritora [podemos trocar aqui por filósofa ou qualquer coisa intelectual ou atributo nomeadamente instituído como masculino]. [E ela continua] Você não pode ser boa demais, não pode ter uma excelência tão grande. Se você tem essa excelência e ainda por cima é mulher, eles detestam e te cortam. Você tem que ser mediano e, se for mulher, só falta te cuspir na cara. ${ }^{18}$

Erika Lust nos mostra que não adianta nem esporrar nem cuspir em nossas caras, pois ainda podemos resistir. E resistimos por dentro, no sistema, criando novos discursos, adentrando a polis, ocupando lugar na Ágora e fazendo política, inclusive produzindo filmes pornográficos.

Mas esse meu texto/ensaio/retalho é sobre corpo, sexo, erotismo e pornografia, então, me aproprio aqui das palavras de Anaïs Nin e tento finalizo, se é possível dizer que há um fim, com um trecho de Michel Foucault. Afinal, meu exercício sempre foi o da Filosofia.

Anaïs Nin em um pós escrito nos toca ao dizer:

Creio que meu estilo era derivado da leitura de obras de homens. Por esse motivo, durante muito tempo achei que havia comprometido meu eu feminino. Deixei a erótica de lado. Relendo-os muitos anos depois, vejo que a minha voz não foi completamente suprimida. Em numerosas passagens usei intuitivamente uma linguagem de mulher, vendo a experiência sexual do ponto de vista da mulher. Finalmente decidi liberar a erótica para publicação, porque mostra os esforços iniciais de mulher em mundo que fora de domínio dos homens.

Se a versão sem cortes do Diário algum dia for publicada, esse ponto de vista feminino será demonstrado mais claramente. Ele mostrará que as mulheres (e eu, no Diário) jamais separaram o sexo do sentimento, do amor pelo homem por inteiro. ${ }^{19}$

E sobre a Filosofia, fico com Foucault...

A história crítica do pensamento não é uma história das aquisições nem das ocultações da verdade; é a história da emergência dos jogos de verdade: é a história das "veridicções" entendidas como as formas pelas quais se articulam, sobre um campo de coisas, discursos capazes de serem ditos verdadeiros ou falsos: quais foram as condições dessa emergência, o preço com o qual, de qualquer forma, ela foi paga, seus efeitos no real e a maneira pela qual, ligando um certo tipo de objeto a certas modalidades do sujeito, ela constituiu, por um tempo, uma área e determinados indivíduos, o $a$ priori histórico de uma experiência possível. ${ }^{20}$

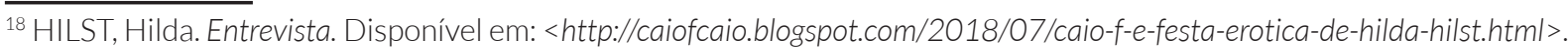

${ }^{19}$ NIN, A. Diários não expurgados: fogo, p. 14-15.

${ }^{20}$ FOUCAULT, Ética, sexualidade e política, p. 235.
} 
84 Posições e Disposições de um corpo: o erótico e o pornográfico na ótica feminina: práticas de submissão ou de resistência nos dispositivos de poder

Tenhamos, então, uma outra experiência possível. Fiquemos com as aspas, as tesouras, os retalhos, as reticências...

\section{Referências}

ANTUNES, Arnaldo. As Coisas. Iluminuras, Rio de Janeiro, 2002.

ARISTÓTELES. De Anima. Traduzido por Maria Cecilia Gomes dos Reis. São Paulo: Editora 34, 2006.

ARISTÓTELES. De Anima. Traduzido por W.S. HETT. Cambridge: Harvard University Press, 2000.

ARISTÓTELES. Metafísica. Tradução de Giovanni Reale. Vol. II. São Paulo: Edições Loyola, 2002.

ARISTÓTELES. Metafísica: sumário e comentários. Tradução Giovanni Reale. Vol. I e III. São Paulo: Edições Loyola, 2002.

BOURDIEU, Pierre. A dominação masculina. 11. ed. Tradução Maria Helena Kühner. Rio de Janeiro: Bertrand Brasil, 2012.

BOURDIEU, Pierre. O poder simbólico. Tradução Fernando Tomaz. Difusão Editorial: Lisboa, 1989.

FOUCAULT, M. In Pol-Droit, Roger. Michel Foucault: entrevista. Graal ed. 2006ª .

FOUCAULT, M. Ética, sexualidade e política. Coleção “Ditos e Escritos”, Vol. V. Rio de Janeiro, Forense Universitária, 2006b.

FOUCAULT, M. Michel Foucault, uma entrevista: sexo, poder e a política da identidade. Tradução Wanderson Flor do Nascimento. Verve, São Paulo, n 5, 2004, p. 260- 277

FOUCAUlT, M. Ditos e Escritos V. Ética, Sexualidade e Política. Rio de Janeiro: Forense Universitária, 2004.

HESÍODO. Teogonia. 2. ed. São Paulo: Iluminuras, 1995.

HILST, Hilda. Entrevista. Disponível em: http://caiofcaio.blogspot.com/2018/07/caio-f-e-festa-eroticade-hilda-hilst.html. Último acesso em: 15 de abril de 2019.

LUST, Erika. Pornografia Feminista. Disponível em: http://lugardemulher.com.br/erika-lust-e-apornografia-feminista/. Último acesso em: 15 de abril de 2019.

MACKINNON, Catharine A. Feminismo, Marxismo, Método e o Estado: Uma agenda Para Teoria. Direito e Práxis revista. Rio de Janeiro, Vol. 07, N. 15, 2016, p. 798-837.

MACKINNON, Catharine A. In Professing Feminism: Cautionary Tales from the Strange World of Women's Studies, p. 129

MACKINNON, Catharine A. Toward a Feminist Theory ofthe State; Cambridge: Harvard University Press, 1989.

MARION, J. L. Le phénomène érotique. Paris: Grasset, 2003.

MORAIS, Eliane R. A pornografia é uma fome, podemos saciá-la com um banquete ou um salgadinho Disponível em: https://azmina.com.br/reportagens/a-pornografia-e-uma-fome-podemos-sacia-lacom-um-banquete-ou-um-salgadinho/. Ultimo acesso em: 15 de abril de 2019.

NiETZSCHE, F. W. Crepúsculo dos ídolos. Trad. de Paulo César de Souza. São Paulo: Companhia das Letras, 2006.

NIETZSCHE, F. W. Crepúsculo dos ídolos. Trad. Edson Bini e Márcio Pugliesi. São Paulo: Hemus, 1976.

NIN, A. Delta de Vênus. Trad. Lúcia Brito. Porto Alegre: L\&PM Pocket, 2013.

NIN, A. Diários não expurgados: fogo. Trad. Guilherme da Silva Braga. Porto Alegre: L\&PM Pocket, 2011.

NIN, A. Entrevista. Disponível em: https://www.youtube.com/watch?v=7SXVzJGA4mk. Último acesso em: 15 de abril de 2019.

SADE. Histoire de Juliette, in Oeuvres Complètes, Paris, Pauvert, 1987, tomo VIII, pp. 598-9. 